\title{
Evaluation of heavy metal concentration in maize grown in selected industrial areas of Ogun State and its effects on urban food security
}

\author{
Malomo Olu", Olufade, O. I., Adekoyeni, O. O., Jimoh, M. O. \\ College of Food Sciences, Bells University of Technology, Ota, P.M.B. 1015, OTA, Ogun State, Nigeria
}

Email address:

oludaremalomo1951@yahoo.com(M. Olu)

\section{To cite this article:}

Malomo Olu, Olufade, O. I., Adekoyeni, O. O., Jimoh, M. O.. Evaluation of Heavy Metal Concentration in Maize Grown in Selected Industrial Areas of Ogun State and its Effects on Urban Food Security. International Journal of Science, Technology and Society. Vol. 1, No. 2, 2013, pp. 48-56. doi: 10.11648/j.ijsts.20130102.12

\begin{abstract}
This project was carried out to investigate the effect industrial pollution as it affects the heavy metal concentrations flared into the atmosphere, washed down by rain and absorb by maize cultivated in industrial areas of Ogun State. This was suspected to have effects on food safety .In addition to determine the effect of soil factor and the accumulation of metals in maize. This study also ascertained the basis for environmental protection and reduction of the negative implication of heavy metals in the human and livestock health. Maize and soil samples were collected from industrial areas in Ogun State and were analyzed for both chemical and metal concentrations. The metals $\mathrm{Fe}, \mathrm{Cu}, \mathrm{Mg}, \mathrm{Ni}$, $\mathrm{Pb}, \mathrm{Ca}$, and $\mathrm{Co}$ were determined using Atomic Absorption Spectrophotometer (AAS). The results of the chemical analysis of the maize collected from the industrial areas of Ogun State ranged between 6.35-9.45\%, 8.31-12.68\%, 1.49-8.294\% $1.746-2.792 \%$, and $71.32-78.896 \%$ for moisture, crude protein, ether extract, and carbohydrate respectively while the chemical analysis of the soil ranged between $0.65-1.90 \%, 6.63-7.89 \%$, and $4.01-8.6 \%$ for moisture, $\mathrm{pH}$, and nitrogen content respectively. The concentrations of the metals $\mathrm{Fe}, \mathrm{Cu}, \mathrm{Mg}, \mathrm{Ni}, \mathrm{Pb}, \mathrm{Ca}$, and $\mathrm{Co}$ in maize ranged between $28.5-$ $59.5 \mathrm{mg} / \mathrm{kg}, 2-10.7 \mathrm{mg} / \mathrm{kg}, 248.3-321 \mathrm{mg} / \mathrm{kg}, 1.8-4.775 \mathrm{mg} / \mathrm{kg}, 62.5-150 \mathrm{mg} / \mathrm{kg}$, and $1.2-10.2 \mathrm{mg} / \mathrm{kg}$ respectively while the concentrations of the soil samples were $28.9-59.6 \mathrm{mg} / \mathrm{kg}, 4-12.2 \mathrm{mg} / \mathrm{kg}, 297.3-350.5 \mathrm{mg} / \mathrm{kg}, 4.55-9.28 \mathrm{mg} / \mathrm{kg}, 83.3-$ $177.5 \mathrm{mg} / \mathrm{kg}, 7.6-21.8 \mathrm{mg} / \mathrm{kg}$, and $0.075-0.46 \mathrm{mg} / \mathrm{kg}$ for $\mathrm{Fe}, \mathrm{Cu}, \mathrm{Mg}, \mathrm{Ni}, \mathrm{Pb}, \mathrm{Ca}$, and Co respectively. Some of the metals such as $\mathrm{Ni}$ in Ewekoro, $\mathrm{Pb}$ in Sango, exceeded the recommended limits proposed by WHO/FAO. The results showed that the high concentrations of certain heavy metals in maize revealed the level of food insecurity and this calls for public concern.
\end{abstract}

Keywords: Heavy Metals, Food Security, Indusrial Pollution, Metal Toxicity, Accumulation of Metals in Maize

\section{Introduction}

Maize (Zea mays) is of paramount importance in the diets of many native African populations. Of the 22 countries in the world where maize forms the highest percentage of energy in the national diet, 16 are in Africa (Dowswell et al., 1996). Maize has made a distinct imprint across African landscapes with nearly $95 \%$ of harvests used for human consumption (Byerlee et al., 1997). Lesotho, Malawi, and Zambia rank as the world's top 3 maizesubsisting countries, surpassing Mesoamerican countries, where the crop originated.

Most maize production in Nigeria is rain fed and 95\% of total maize production is consumed locally compared to the
World regions that use most of its maize as animal feed. This is evident in Nigerian meal as consumption of maize cut across all economy classes especially at its seasons as either boiled or roasted. Nutritionally, it has high content of carbohydrates, fats, proteins, and some of the important vitamins and minerals, the crop has acquired a well deserved reputation as a poor man's nutricereal (Punita, 2006).

In recent times, urban agriculture seems to have gained importance especially in developing economies. This is basically because it has been discovered to be a viable intervention strategy for the urban poor to earn extra income by growing their own food. It is a major component of the urban foods system to provide the diversity needed to ensure dietary quality, which is an important aspect of food 
security options for households.

Nelson (1996) stated that, about 200 million urban dwellers participate in urban farming. Similarly, it is one of the several tools for making productive use of urban open spaces, treating and/or recovering urban solid and liquid wastes, saving or generating income and employment and managing fresh water resources more effectively.

However, with the current emphasis on eating more healthy diets and public concerns on presence of heavy metals in foods or agricultural produce, it is very essential to assess the chemical composition and heavy metal concentration in maize, as one of the major crops that is usually cultivated in urban area and also popularly consumed by people. The presence of essential metals like iron, copper, zinc, magnesium are associated with enzyme systems particularly those involved in oxidation process and other important biochemical process (Akaninwor et $a l ., 2006)$. They are very useful for the healthy growth of the body though very high levels are intolerable.

Metals like mercury, lead, cadmium and arsenic are toxic at very low concentrations (Nkansah et al, 2010). Though most heavy metals are needed in trace amounts by growing plants, their excess can result in plant intoxication. The occurrence of heavy metals in industrial wastewater is of interest because they are often present at significant levels and if discharged into surface waters can have severe effects on the environment and public health. Thus the presence of concentrations of heavy metal in plant tissues brings about poisoning problems in human beings and other animals feeding on specific plant tissues (Alloway et al, 1995).

These heavy metals have the potential hazardous effect, not only in compounds but also on human health. This is due to their cumulative properties and toxicity although they are generally present in agricultural soils at low levels. Increasing industrialization has been accompanied throughout the world by the extraction and distribution of mineral substances from their natural deposits. However, there are large scale industries in Nigeria, both privately and publicly owned. These include cement, pharmaceuticals, paint, ceramics, roofing sheets, agro allied, beverages and so on. The auditing and monitoring of metals in the environment (soil, water and foods) is fast becoming an essential aspect of pollution studies, particularly in industrialized area.

The rampant use of chemical fertilizers contributes largely to the deterioration of the environment through depletion of fossil fuels, generation of carbon dioxide (CO2) and contamination of water resources. This loss of soil fertility due to imbalance use of fertilizers has adversely impacted agricultural productivity and causes soil degradation. Now there is a growing realization that the adoption of ecological and sustainable farming practices can only reverse this declining trend in the global productivity and environment protection. Therefore, in order for wastewater irrigation to be sustainable there is need for careful and planned management to ameliorate the negative impacts that may arise. The study carried out in Zimbabwe on heavy metals concentrations in maize were on high side. The concentrations of heavy metals in plants also depend on application rate, soil reactions and plant species (Zoubi, 2008).

Urban agriculture may have a role to play in addressing urban food insecurity problems, which are bound to become increasingly important with the secular trend towards the urbanization of poverty and of population in developing regions. However, the safety of the food must also be of concern because of the deleterious effects of heavy metal contamination to human health. Hence, this work was aimed at determining the effect of concentration of heavy metal uptake by maize and soil on urban food security in industrial areas of Ogun state.

\subsection{Food Security}

Food security and food availability can be considered at two different points. One is urban areas, where food crops are not produced and residents are principally not food producers (Benson, 2004.). The other is rural areas, where the majority of residents are small-scale farmers who are both food-crop producers and food consumers. Urban resident food security and that of rural residents who are not food self sufficient depends on surplus food crops produced by farmers (Jayne et al., 2007). Therefore, smallscale farm production can influence food security in two ways:

1) It influences small-scale farmers' household food selfsufficiency (whether they can produce a sufficient amount of food crops for their own consumption); and

2) It influences national food security (production of surplus food crops for urban residents and rural residents who are not food self-sufficient).

It is generally accepted that "food security" has three critical components: food availability, food access, and food use and utilization (FFSSA, 2004). Policies aimed at improved food security must address these three components. Food security has been discussed from two different perspectives: social protection and economic growth or development. It is difficult to draw clear boundaries between social protection and growth-oriented activities. It is more productive to explore some of the synergies or linkages between the two (FFSSA, 2004).

A comprehensive view of food security, i.e., one that considers both food availability and food access, requires thinking toward a broader view of social protection. Social protection serves three functions: protection, prevention, and promotion (Ellis et al., 2009).

However, availability is not enough. The food produced must be distributed efficiently at minimum costs in-order to guarantee continuous availability of the food. This is the subject of food marketing. Olayemi (1982) observed that food marketing is a very important but rather neglected aspect of agricultural development. More emphasis is usually placed, by government on policies to increase food production with little or no consideration on how to 
distribute the food produced efficiently and in a manner that will enhance increased productivity.

A good and well-coordinated national food marketing system can affect food production and household's food security in two ways. One, it can stimulate increased commercial activities that could generate more funds for plough back investments in both agricultural and agroallied industrial sectors. The resultant increased agricultural productivity will lead to increased food production and increased food output.

Secondly, it can lead to employment generation for both food distributors and rural farmers. The involvement of rural people in food marketing could uplift the rural populace standard of living and increase their personal income thereby enhancing the prospect of food security at the households, local and national levels.

Availability of food at the household level requires that food must be available either through their own-farm operations or by purchasing the food from the market. In most cases, the food produced from own-farm operation is inadequate and this makes a good marketing system very important to ensure food availability.

\section{Materials and Method}

\subsection{Study Site}

The study site for this research includes farmlands at Agbara, Abeokuta, Owode, Sango, Papalntoro, Ijebu-ode, Sagumu, Ewekoro. The farmlands are located within various industrial areas of Ogun State Nigeria. Both maize cobs and soil samples were collected from these industrial areas.

\subsection{Sample Collection and Preparation}

Soil samples were collected from areas of known contamination. Plastic spade was used to collect soil from a depth not deeper than topsoil $(0-15 \mathrm{~cm})$ into polythene bags. These bags were then carried to the laboratory. $20 \mathrm{~g}$ of the sample was taken from each sample, air dried and crushed to pass through a $2 \mathrm{~mm}$ sieve and stored in another polythene bag which was then used for the various analysis.

The maize cobs were shelled manually and then cleaned. The samples were dried at $60^{\circ} \mathrm{C}$ for six hours using an oven and a dry milling machine. The maize was then stored to carry out further various analyses.

\subsection{Chemical Analyses on Maize}

The maize collected was analyzed for moisture, protein, ether extract, ash and carbohydrate content using standard method of analyses.

\subsection{Determination of Moisture Content}

The moisture content was determined by the method described by AOAC (2000). Five grams of each sample was weighed into pre - weighed clean drying dish. The dish was placed in a well ventilated laboratory hot air oven (Surgifriend Medicals, England. SM9053) maintained at $105^{\circ} \mathrm{C}$. The weight of the sample plus the drying dish was checked at hourly interval after the first two hours until the decrease in mass between successive weighing did not exceed $0.05 \mathrm{mg}$ per $\mathrm{g}$ of sample. The loss in weight was reported as the moisture content and calculated as follows:

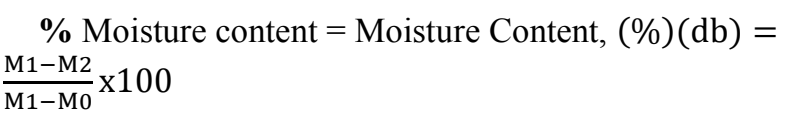

Where $\mathrm{M}_{0}$ = weight of the empty dish before drying $\mathrm{M}_{1}$ = weight of the dish and the sample before drying $\mathrm{M}_{2}=$ weight of the dish and the sample after drying.

\subsection{Protein}

The Protein Content was determined using a Foss Tecator $^{\mathrm{Tm}}$ protein digestor and KJECTECK 2200 distillation apparatus (Kjeldahl method) according to the procedure of AOAC, (1990). Concentrated $\mathrm{H}_{2} \mathrm{SO}_{4}\left(12 \mathrm{~cm}^{3}\right)$ and 2 tablets of catalyst were put into a Kjeldahl digestion flask containing $5 \mathrm{~g}$ of the sample. The flask was placed in the digestor in a fume cupboard and switched on and digestion was done for 45 minutes to obtain a clear colourless solution. The digest was distilled with $4 \%$ boric acid, $20 \%$ Sodium hydroxide solutions were automatically metered into it in the KJECTEC 2200 distillation equipment until distillation was completed. The distillate was then titrated with $0.1 \mathrm{M} \mathrm{HCl}$ until a grey colour formation indicating the end point. A blank was run under the same condition as with the sample. Total nitrogen content was then calculated according to the formula:

$$
\begin{aligned}
& \text { Protein, }(\%)=\frac{(\text { Titre-Blank }) \times 14.007 \times 0.1 \times 100}{1000 \times \text { sample weight }(\mathrm{mg})} \\
& \text { Crude Protein, \% } \% \mathrm{~N} \text { multiplied by } 6.25 \\
& \text { Where } 6.25 \text { is a constant }
\end{aligned}
$$

\subsection{Ash Content}

$2 \mathrm{~g}$ of the sample was weighed into well incinerated crucibles and then ashed in a muffle furnace at $600^{\circ} \mathrm{C}$ for 3 hours. The ash content was calculated as

Ash Content $=$

$\frac{\text { (weight of crucible +ash) }- \text { (weight of empty crucible }}{\text { weight of sample }} \times 100$

\subsection{Crude Fat}

The fat contents were determined using the method described by AOAC (2000). The principle of Soxhlet fat extraction method was used but with a modern fat extractor with automated control unit (Foss Soxtec 2055, Foss Tecator Analytical AB Hoganas, Sweden). 1g of samples were weighed into extraction thimbles and then stopped with grease-free cotton. The extraction cups were cleaned, dried, weighed and $80 \mathrm{ml}$ of petroleum ether were measured into each cups and the heating temperature adjusted to 
$155^{\circ} \mathrm{C}$ which is the extraction temperature for fat using petroleum ether as stated in the manual. The cups were set into the Soxtec unit with each cup aligning with its respective thimble. There are three stages involved; the boiling/extraction, rinsing and the drying. The extraction stage was for 30minutes in 'boiling' position and 30 minutess in 'rinsing' position after which it was aerated for 15 minutes. The cups were removed, cooled in a dessicator and weighed.

$$
\text { Crude Fat }=\frac{\text { (weight of cup }+ \text { fat })-(\text { weight of empty cup }}{\text { weight of sample }} \times 100
$$

\subsection{Carbohydrate and Metabolizable Energy Determination}

The carbohydrate content was estimated by difference.

The metabolizable energy $(\mathrm{kcal} / 100 \mathrm{~g})$ was determined using Atwater general conversion system as described by FAO (2002).

\subsection{Mineral Content Determination}

The dry digestion (ashes) procedure was used for the preparation of the samples for mineral analysis. One (1) gram of the sample was accurately weighed into porcelain crucibles and pre-ashed until the sample was completely charred on a hot plate. The pre-ashed samples were thereafter ashed in the muffle furnace at $550^{\circ} \mathrm{C}$ till the ash was white for about 2 hours. After ashing, the crucible was transferred into the desiccator to cool. The sample was transferred into $100 \mathrm{ml}$ volumetric flasks and carefully washing the crucibles with $0.1 \mathrm{M}$ of $\mathrm{H} 2 \mathrm{SO} 4$. This was made up to $100 \mathrm{ml}$ measurement of the volumetric flask with deionised water. The content of the minerals; calcium, magnesium, copper and iron were determined with the Atomic Absorption

Spectrophotometer (Buck Scientific, Model 210).

Calculation

\%Mineral Element Concentration=

$\frac{\text { Machine reading }(\mathrm{ppm})}{\text { Weight of sample }} \times$ dilution factor(100)

\subsection{Soil Analysis}

The analysis carried out on soil samples included $\mathrm{pH}$, moisture content, nitrogen and metal concentrations. The details of the analyses were given below:

\subsection{1. pH Determination}

The air dried soil samples that was ground and passed through a $2 \mathrm{~mm}$ sieve, was analyzed for $\mathrm{pH}$. The $\mathrm{pH}$ was carried out by dipping the electrode of the $\mathrm{pH}$ meter into the suspension of 1:1 soil/water sample. The readings were obtained from the photo-detector on the $\mathrm{pH}$ meter.

\subsection{Soil Moisture Content}

The Moisture Content was determined using procedure described by AOAC, (1990). The moisture content of each sample was determined by weighing $5 \mathrm{~g}$ of the sample into Aluminum moisture can. The sample was then dried to constant weight at $105^{\circ} \mathrm{C}$ for 3 hours.

$\%$ Moisture content=Moisture Content, $(\%)=$ $\frac{\mathrm{M} 1-\mathrm{M} 2}{\mathrm{M} 1-\mathrm{M} 0} \times 100$

Where $\mathrm{M}_{0}=$ weight of the empty dish before drying $\mathrm{M}_{1}=$ weight of the dish and the sample before drying $\mathrm{M}_{2}=$ weight of the dish and the sample after drying.

\subsection{Nitrogen}

The Nitrogen Content was determined using a Foss Tecator $^{\mathrm{Tm}}$ protein digestor and KJECTECK 2200 distillation apparatus (Kjeldahl method) according to the procedure of AOAC, (1990).

Concentrated $\mathrm{H}_{2} \mathrm{SO}_{4}\left(12 \mathrm{~cm}^{3}\right)$ and two tablets of catalyst were put into a Kjeldahl digestion flask containing $5 \mathrm{~g}$ of the sample. The flask was placed in the digestor in a fume cupboard and switched on and digestion was done for 45 minutes to obtain a clear colorless solution. The digest was distilled with $4 \%$ boric acid, $20 \%$ Sodium hydroxide solutions were automatically entered into it in the KJECTEC 2200 distillation equipment until distillation was completed. The distillate was then titrated with $0.1 \mathrm{M} \mathrm{HCL}$ until a violet color formation indicating the end point. A blank was run under the same condition as with the sample. Total nitrogen content was then calculated according to the formula:

$$
\text { Nitrogen }=(\%)=\frac{(\text { Titre }- \text { Blank }) \times 14.007 \times 0.1 \times 100}{1000 \times \text { sample weight }(\mathrm{mg})}
$$

\subsection{Determination of Metal Concentrations}

The wet digestion method was used for the preparation of the soil samples for mineral analyses. $2 \mathrm{~g}$ of the samples were weighed into the digestion tubes with $5 \mathrm{ml}$ each of concentrated $\mathrm{HNO} 3$ and $\mathrm{CCLO} 3$ of the same ration to digest the samples on heating digestor at $400^{\circ} \mathrm{C}$ (Tacator digestor 220). After formation of clear solution, the samples were allowed to cool and were later transferred into $100 \mathrm{ml}$ volumetric flasks and made up with de-ionized water. The content of the minerals; calcium, magnesium, copper and iron were determined with the Atomic Absorption Spectrophotometer (Buck Scientific, Model 210).

Calculation

\%Mineral Element Concentration=

$\frac{\text { Machine reading }(\mathrm{ppm})}{\text { Weight of sample }} \mathrm{x}$ dilution factor $(100)$

\subsection{Determination of Bioaccumulation Coefficient}

Statistical procedure was employed to calculate the bioaccumulation coefficient as shown below:

Bioaccumulation coefficient $=\frac{\text { Lead content in maize }}{\text { lead content in soil }}$ 


\section{Results and Discussion}

\subsection{Proximate Compositions of Maize from Industrial Areas of Ogun State}

The proximate composition of maize collected from the industrial areas of Ogun State ranged between 6.35-9.45\%, $8.31-12.68 \%, 1.49-8.294 \% 1.746-2.792 \%$, and $71.32-$ $78.896 \%$ for moisture, crude protein, ether extract, ash, and carbohydrate respectively. The results are presented in the table 4.1.

Table 1: Proximate composition of maize from selected industrial areas of Ogun State

\begin{tabular}{|c|c|c|c|c|c|}
\hline $\begin{array}{l}\text { Industrial Moisture } \\
\text { area content(\%) }\end{array}$ & $\begin{array}{l}\text { Protein } \\
\text { Content (\%) } \\
\end{array}$ & $\begin{array}{l}\text { Fat Extract } \\
(\%)\end{array}$ & $\begin{array}{l}\text { Ash content } \\
(\%)\end{array}$ & Carbohydrate (\%) & $\begin{array}{l}\text { Metabolizable } \\
\text { energy(kcal/100g) }\end{array}$ \\
\hline Sango $9.4 \pm 0.17$ & $9.08 \pm 1.16$ & $4.60 \pm 0.13$ & $2.05 \pm 0.17$ & $75.23 \pm 0.70$ & $378.68 \pm 0.84$ \\
\hline Рара $7.65 \pm 0.03$ & $12.06 \pm 0.55$ & $6.57 \pm 0.32$ & $2.40 \pm 0.14$ & $71.32 \pm 40$ & $392.63 \pm 2.31$ \\
\hline Owode $7.75 \pm 0.03$ & $8.67 \pm 0.88$ & $8.29 \pm 0.25$ & $1.90 \pm 0.06$ & $73.39 \pm 1.05$ & $402.89 \pm 1.60$ \\
\hline Ewekoro $9.00 \pm 1.16$ & $12.68 \pm 0.39$ & $1.50 \pm 0.14$ & $2.95 \pm 0.047$ & $73.07 \pm 0.90$ & $356.50 \pm 3.87$ \\
\hline Abeokuta $7.95 \pm 0.44$ & $9.88 \pm 0.12$ & $6.04 \pm 0.005$ & $1.75 \pm 0.15$ & $74.68 \pm 0.20$ & $392.62 \pm 0.75$ \\
\hline Agbara $7.75 \pm 0.09$ & $8.31 \pm 0.35$ & $12.85 \pm 0.15$ & $2.79 \pm 0.03$ & $78.90 \pm 3.53$ & $464.49 \pm 14.19$ \\
\hline Ijebu-ode $6.35 \pm 1.13$ & $10.89 \pm_{0.43}$ & $6.45 \pm 0.08$ & $2.25 \pm 0.26$ & $74.06 \pm 1.90$ & $397.85 \pm 5.10$ \\
\hline Sagamu $6.90 \pm 0.35$ & $12.31 \pm 0.13$ & $5.83 \pm 0.10$ & $1.90 \pm 0.12$ & $73.06 \pm 0.50$ & $393.94 \pm 0.35$ \\
\hline
\end{tabular}

The result of protein contents of maize showed that samples of maize from Ewekoro have the highest amount of protein followed by samples from Sagamu with $12.68 \%$ and $12.35 \%$ values respectively. The least value of protein was obtained from samples of maize from Owode. The values of the protein contents recorded were higher than the values documented by Watson (1962) but were comparable to the report of Malomo et al., (2012). The ash content represents the total mineral composition of maize. The highest amounts of minerals were found in maize from Ewekoro $(2.95 \%)$ while the least were in maize samples from Abeokuta (1.746\%). Maize is a starchy food and it's rich in carbohydrate. This is responsible for the high carbohydrate as shown (Table 4.1). It is also revealed that the samples of maize are good source of metabolizable energy. The amount of metabolizable energy is determined by the composition of protein, fat and carbohydrate content and their ratio in foods (FAO, 2002).

The chemical composition is related to the findings of Ibrahim and Halla, (2007), but the moisture content is lower. It is estimated that several million people, particularly in the developing countries derive their protein from maize and calorie (11.1g and $342 \mathrm{Kcal} /$ day) requirement from maize. It is quite observed that the nutritional quality of maize contribute immensely toward eradicating food insecurity in the urban area.

\subsection{Chemical Compositions of Soil from Industrial Areas of Ogun State}

The proximate composition of maize collected from the industrial areas of Ogun State ranged between 0.65-1.90\%, 6.63-7.89 \%, and 4.01-8.6\% for moisture, $\mathrm{pH}$, and nitrogen content respectively. The results are represented in Table 2
Table 2: Result of proximate composition of soil

\begin{tabular}{|c|c|c|c|}
\hline $\begin{array}{ll}\text { Industrial } & \text { area } \\
\text { Content( } \%) & \\
\end{array}$ & Moisture & pH (\%) & $\begin{array}{l}\text { Nitrogen } \\
\text { content }(\%) \\
\end{array}$ \\
\hline Sango $1.05 \pm 0.17$ & & $6.67 \pm 0.21$ & $4.5 \pm 0.23$ \\
\hline Papa $1.65 \pm 0.20$ & & $6.63 \pm 0.09$ & $4.55 \pm 0.03$ \\
\hline Owode $0.75 \pm 0.03$ & & $7.55 \pm 0.03$ & $6.5 \pm 0.40$ \\
\hline Ewekoro $1.6 \pm 0.09$ & & $7.24 \pm 0.13$ & $5.25 \pm 0.41$ \\
\hline Abeokuta $1.9 \pm 0.12$ & & $6.77 \pm 0.03$ & $5.4 \pm 0.17$ \\
\hline Agbara $1.13 \pm 0.08$ & & $7.89 \pm 0.07$ & $4.01 \pm 0.18$ \\
\hline Ijebu-ode $0.85 \pm 0.06$ & & $6.84 \pm 0.00$ & $5.6 \pm 0.17$ \\
\hline Sagamu $0.65 \pm 0.16$ & & $7.45 \pm 0.01$ & $5.1 \pm 0.06$ \\
\hline
\end{tabular}

The result of low moisture content was as a result of drying of the samples of soil as part of the standard procedure designed for the field collection of soil sample. Abeokuta has the highest level of moisture (1.9\%) followed by Papa which has a moisture content of (1.65\%) and also followed by that of Ewekoro (1.6\%). These places are considered to be close to each other and this is also because of their geographical closeness to each other, hence the tendency to have similar soil type and structure. Whilst the lowest level of moisture was from soil samples collected at Sagamu $(0.65 \%)$. The soil water is affected by several factors such soil type, soil structure, soil composition especially presence of organic component and soil porosity.

The level of $\mathrm{pH}$ observed from the table 4.2 shown a range of slightly acidic to neutral to slightly alkaline (6.637.89). Soil $\mathrm{pH}$ regulates almost all biological and chemical reactions in the soil (Brady et al., 2002; Kabata-Pendias, 
2001), thus the distribution of $\mathrm{pH}$ may provide a useful index for the potential soil holding capacity for heavy metals, nutrients and fertility of soil types. This suggests that, the $\mathrm{pH}$ of soils may determine the solubility's of metals in soil solution and their erosion pattern in the farmland soils.

The nitrogen level was relatively low as compared to the industrial area from where they were sourced. The area with the lowest level of nitrogen was at Agbara (4.01\%) followed by that of Sango (4.5\%). Nitrogen is one of the most important plant nutrients and forms some of the most mobile compounds in crop system and as such is commonly related to water quality problems.

\subsection{Metal Concentrations in Maize and Soil from Industrial Area of Ogun State}

The maize and soil samples from the different industrial areas under investigation reveal varying concentrations on all seven analyzed heavy metals $(\mathrm{Cu}, \mathrm{Mg}, \mathrm{Pb}, \mathrm{Ca}, \mathrm{Fe}, \mathrm{Ni}$, $\mathrm{Co})$. The results of maize and soil metal concentrations were shown in the tables ( 3 and 4 ) respectively.

Table 3: Results of metal concentrations in maize from industrial area of Ogun State

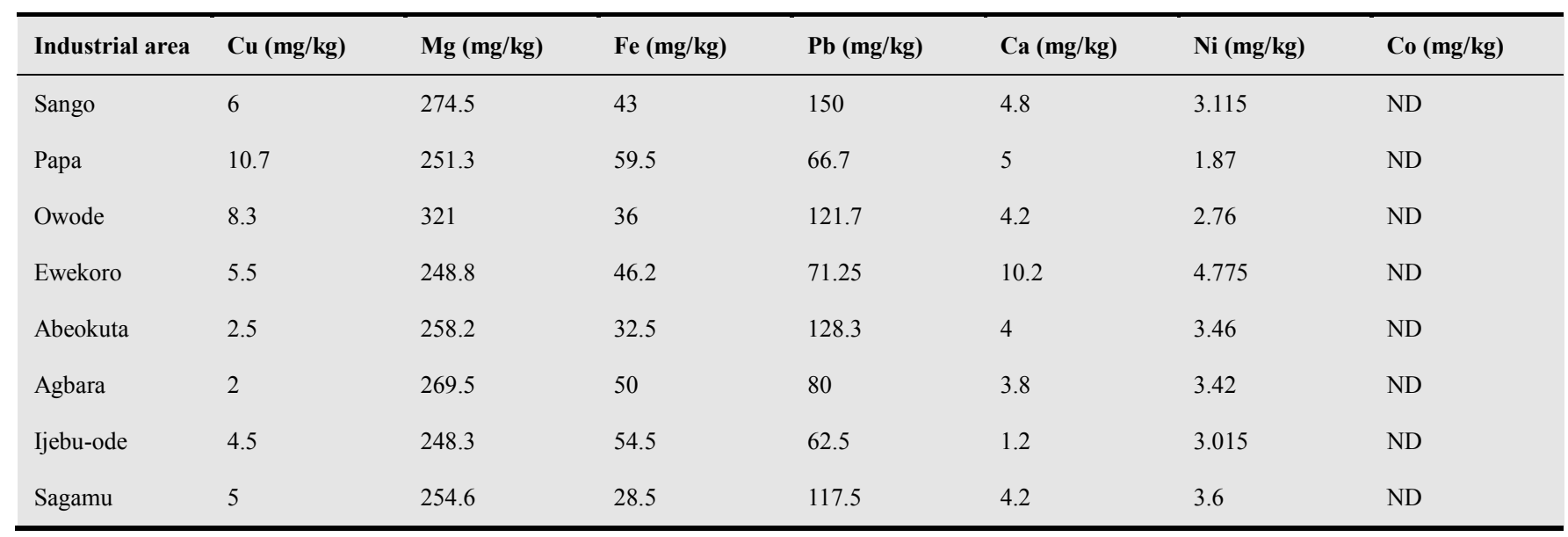

Table 4: Results of metal concentration in soil from industrial area of Ogun State

\begin{tabular}{|c|c|c|c|c|c|c|}
\hline Industrial area $\mathrm{Cu}(\mathrm{mg} / \mathrm{kg})$ & Mg (mg/kg) & Fe (mg/kg) & $\mathrm{Pb}(\mathrm{mg} / \mathrm{kg})$ & $\mathrm{Ca}(\mathrm{mg} / \mathrm{kg})$ & $\mathrm{Ni}(\mathrm{mg} / \mathbf{k g})$ & Co $(\mathrm{mg} / \mathrm{kg})$ \\
\hline Sango 7 & 348.7 & 42.3 & 177.5 & 8.4 & 6.61 & ND \\
\hline Papa 11.5 & 297.3 & 59 & 96.7 & 10 & 6.53 & ND \\
\hline Owode 12.2 & 350.5 & 40.7 & 151.25 & 8.2 & 7.14 & ND \\
\hline Ewekoro 7.5 & 345.9 & 52.8 & 105 & 21.8 & 9.28 & 0.46 \\
\hline Abeokuta 3.75 & 301.7 & 31.2 & 141.7 & 7.6 & 3.535 & 0.305 \\
\hline Agbara 4 & 322.6 & 59.6 & 100 & 10.8 & 8.45 & ND \\
\hline Sagamu 7.7 & 298.4 & 28.9 & 127.5 & 12.6 & 4.55 & 0.075 \\
\hline
\end{tabular}

There were noticeable differences in the concentration of metals in maize and soil in each sample depending on their different locations. For $\mathrm{Cu}$, the area with the highest level was Papa $(10.7 \mathrm{mg} / \mathrm{kg})$ followed by Owode $(8.3 \mathrm{mg} / \mathrm{kg})$ and the least $\mathrm{Cu}$ concentration was at Agbara $(2 \mathrm{mg} / \mathrm{kg})$. However the results gathered were below the safe recommended limits of $40.00 \mathrm{mg} / \mathrm{kg}$ (WHO/FAO Codex alimentary commission (1984) and the maximum safe level of $20 \mathrm{mg} / \mathrm{kg}$ set by (Standard Organisation of Nigeria (SON). The recommended daily allowance for $\mathrm{Cu}$ is $0.9-2.0$ $\mathrm{mg} / \mathrm{D}$. The major sources of $\mathrm{Cu}$ contamination into the maize could be as a result of mining, pesticides, production, chemical industry, metal piping. However, Papa Lantoro is an area very close to industrialization, which gives it a high $\mathrm{Cu}$ level. If an overdose of it is injected or inhaled into the human body, it could cause kidney damage, stomach and intestinal irritation. The result of $\mathrm{Cu}$ concentrations in the soil showed that the highest level was in Owode (12.2 $\mathrm{mg} / \mathrm{kg}$ ) followed by that of Papa Lantoro $(11.5 \mathrm{mg} / \mathrm{kg})$. 
Table 5: The bioaccumulation coefficient of lead uptake in industrial areas of Ogun state

\begin{tabular}{ll}
\hline Location & $\begin{array}{l}\text { Bioaccumulation } \\
\text { Coefficient }\end{array}$ \\
\hline SANGO & 0.845 \\
PAPA & 0.69 \\
OWODE & 0.805 \\
EWEKORO & 0.679 \\
ABEOKUTA & 0.905 \\
AGBARA & 0.8 \\
IJEBU-ODE & 0.75 \\
SAGAMU & 0.922 \\
\hline
\end{tabular}

Magnesium is the most abundant of all the metals examined. The result obtained for the magnesium ranged between $248-321 \mathrm{kcal} / 100 \mathrm{~g}$. The highest level of $\mathrm{Mg}$ was obtained at Owode $(321 \mathrm{mg} / \mathrm{kg})$. Maize has been proven to be one of the major sources of magnesium to human. Farm practice methods, variety of the species of maize cultivated, soil type, and other forms of human activities might have contributed to the amount of magnesium obtained. The results were compared to that obtained from the soil analysis. And the level that had the highest $\mathrm{Mg}$ was also found in Owode $(350.5 \mathrm{mg} / \mathrm{kg})$. It was observed that the level of $\mathrm{Mg}$ in the soil may affect the level found in the maize through the absorption by the maize root system.

The Fe concentration obtained for the maize was highest in Papa $(59.5 \mathrm{mg} / \mathrm{kg})$. Fe is a common element in plants and humans. Thus, Fe has a relatively high WHO levels in food. Deleterious effects of daily intakes between $25-75 \mathrm{mg}$ are unlikely in healthy persons (Ozkutlu et al., 2011). The safety limit of Fe is high as coated by Nkansah et al., 2010 $(300 \mathrm{mg} / \mathrm{kg})$. The recommended dietary allowance for Fe is in the range of $8-15 \mathrm{mg}$. High concentration of Fe can pose risk to the consumer. Excess $\mathrm{Fe}$ is toxic and has been reported to inhibit the absorption of $\mathrm{Zn}$ (Solomons and Ruz, 1997) and the people are prone to increase adverse effect and death due to malaria and communicable diseases (Najat, 2008). The level of Fe obtained from the soil was compared which showed that Agbara $(59.6 \mathrm{mg} / \mathrm{kg})$ was higher than that of Papa $(59 \mathrm{mg} / \mathrm{kg})$ by $0.6 \mathrm{mg} / \mathrm{kg}$.

The lead accumulation of maize was high side as compared to similar work by Malomo et al 2012. They exceed the limits of WHO/FAO (1984). The level of lead that was observed in the soil was higher than that in the maize. This ascertains the fact that lead in the soil greatly affects that in the maize. The highest level was found to be in Sango $(150 \mathrm{mg} / \mathrm{kg}$ and $177.5 \mathrm{mg} / \mathrm{kg})$ for both maize and soil respectively. Lead has no known essential function in human and is a well known metal that damages the liver, kidneys, brain central nervous and reproductive system of man (Lovei et al., 2000). Major sources of lead pollution are paint, pesticide, smoking, automobile emission, mining, burning of coal. These may have been the cause of the high levels that occurred in the maize.

Cobalt accumulation in maize was not detected. Co was only found in trace amount in the soil except at Ewekoro $(0.46 \mathrm{mg} / \mathrm{kg})$ which was found to be very high. Co is a known human carcinogen and which can therefore affect the human lungs and cause diseases.

The highest amount of Nickel was found in maize from Ewekoro $(4.775 \mathrm{mg} / \mathrm{kg}$ ) and the least was recorded in Papa $(1.87 \mathrm{mg} / \mathrm{kg})$. However, the level that was discovered in the soil was highest at Ewekoro $(9.28 \mathrm{mg} / \mathrm{kg}$ ) while the lowest was at Abeokuta $(3.535 \mathrm{mg} / \mathrm{kg})$. The highest level of tolerance of $\mathrm{Ni}$ in the body is $7.6 \mathrm{mg} / \mathrm{kg}$. Ni is essential in small quantity, but when the uptake is too high it can be a danger to human health. High uptake can cause lung embolism, birth defects, respiratory failure, asthma and chronic bronchitis, heart disorder, and allergic reactions such as skin rashes.

Calcium level observed from the maize and soil are both high at Ewekoro $10.2 \mathrm{mg} / \mathrm{kg}$ and $21.8 \mathrm{mg} / \mathrm{kg}$ respectively. Calcium is the most abundant metal in the human body; it is the main constituent of the bones and teeth and also has keys metabolic functions. The use of more than $2.5 \mathrm{~g}$ of calcium per day without a medical necessity can lead to the development of kidney stones and sclerosis of the kidney and blood vessels.

It was observed that the level of metals in the soil greatly influences that of the maize. Heavy metal pollution can originate from natural and anthropogenic sources. Activities such as mining and smelting operations, agriculture and industrial waste have contaminated extensive areas of the world such as Nigeria (Malomo et al 2012). They have been found to be abundant in the soil and relatively small portion in the atmosphere at a particular vapour level. Metal toxicity in plants vary with plant species, specific metal concentrations, chemical forms, soil composition and $\mathrm{pH}$ (Mukesh et al., 2008)

\subsection{Bioaccumulation Coefficient of Lead Uptake}

It could be seen that as the level of lead increases in the soil sample, with a corresponding increase in the level of lead in the maize. This observation could be due to the fact that when lead concentration in the soil is high, lead could react with salts like sodium chloride $(\mathrm{NaCl})$, with a radical exchange form compound $(\mathrm{PbCl})$, which plant is unable to readily absorb, unlike sodium chloride, thus leading to decrease in levels of lead in maize.

During metal transportation from soil through plants, metals got bound largely in the maize which explains why most metals taken are better found in the soil of the plant. The highest level of uptake was found in Sagamu (0.922) and lowest was found at Ewekoro (0.679).

\subsection{Implication for Food Security}

According to the FAO (2003), food security exists when all people, at all times, have physical, social and economic access to sufficient, safe and nutritious food which meets their dietary needs and food preferences for an active and healthy life. The very fact that new mine tailings have been 
found next to agricultural land in the study area should be considered as a threat to food safety. It is very important to highlight that Ewekoro is very high in $\mathrm{Ni}$ and $\mathrm{Co}$, while Sango is very high in $\mathrm{Pb}$. Those metals are highly toxic and could be bioaccumulated and transferred to the food chain. This is of particular relevance because of the potential adverse effects on health and food security of people in the region.

A second reason of concern is the high levels of $\mathrm{Fe}, \mathrm{Mg}$, $\mathrm{Cu}$ found in both maize and soil. It should be noted that $\mathrm{Cu}$ and $\mathrm{Mg}$ are not considered toxic for humans but are toxic for plants and for this reason some countries have posed restrictions to their concentrations in soil. This is of particular relevance because a higher concentration of these elements hinders the development of plants and could reduce land productivity and access to food

\section{Conclusion and Recommendation}

Maize has maintained its position as an important nutricereal with its nutrient profile in Africa, especially in Nigeria. It revealed considerable protein content, high carbohydrate and metabolizable energy. The proximate composition from both the soil and the maize were related. Consumption of maize with elevated levels of essential and non-essential metals can lead to the accumulation of metals in the body and result to health disorder.

Heavy metals $(\mathrm{Pb}, \mathrm{Co}, \mathrm{Ni})$ varied between the soil and maize investigated, which reflect the differences in their mineral uptake and or effect of pollution. Industrialization and their pollution effects might have also been responsible for high metals recorded in some areas such as Papa. High levels of metals above safe limit in staple food like maize called for public concern and this revealed the importance of regular monitoring of heavy metals in staple foods grown in Industrial areas to avert health risks related to excessive mineral ingestion.

Monitoring of these metals is to reduce the rate of food insecurity and ensure safe, sufficient and nutritious food which meets daily needs and food preferences for an active and healthy lifestyle. There is therefore need for satisfactory soil quality monitoring procedures so as to prevent potential health hazards of metals on agricultural land. The concentration of heavy metals in plants is a function of the application rate, soil reactions (including soil type) and plant species therefore future studies should also aim at determining the appropriate application chemical rates on various types of crops.

Appropriate regulatory bodies should ensure proper filtration or treatment of industrial emission to avoid hazards which characterize environmental pollution.

\section{References}

[1] A.O.A.C, (1990). Official methods of Analysis. Association of Analytical chemists. Washinton D.C. 1: 73 -74
[2] A.O.A.C. (2000). Official method of analysis 17 th edition, Horowitz edition intern, Maryland, USA. Vol. 1\& “; 452456.

[3] Akaninwor, J. O., Onyeike, E. N., Ifemeje, J. C (2006). Trace metal levels in raw and heat processed Nigerian stable food from oil producing areas of rivers and Bayelsa States. J. Applied Sci. Environmental Management. 10(2); 23-27.

[4] Alloway, B. J. and Ayres, D. C. (1995). Heavy metals in soil, blackie academics and professional 284-305.

[5] Benson, T. (2004). Africa's Food and Nutrition Security Situation: Where Are We and How Did We Get Here? International Food Policy Research Institute, Washington, D.C.

[6] Brady, N.C and Weil, R.R. (2002). Elements of the nature and properties of soil. Prentice hall. There is no lab manual. $\mathrm{Lab}$ instructions will be posted in the course website. Text teaching assistant: jen loudon; jloudon@AESOP.rutgers.edu $11: 375: 360$

[7] Byerlee., D; and Heisey. 1997. "Evolution of the African maize economy. "In D. Byerlee and C.K. Eicher (eds), Africa's emerging maize revolution. Boulder, Colorado: Lynne Rienner Publishers

[8] Dowswell, CR, Paliwal, RL, Cantrell, RP., (1996): Maize in the Third World, Westview Press, Boulder, Colorado. .

[9] FAO (2002). Food Energy - Methods of analysis and convertion factors. Report of a technical workshop. Rome, 3-6 December, 2002.

[10] FAO (2003), Trade Reforms and Food Security: Conceptualizing the linkages, Rome: FAO.

[11] FAO. (1996). Urban Agriculture: An Oxymoron? In. The State of Food and Agriculture 1996

[12] FFSSA (Forum for Food Security in Southern Africa) (2004). Achieving Food Security in Southern Africa: Policy Issues and Options. FFSSA Synthesis Paper. Online. http://odi.org.uk/work/projects/03-food-security forum/docs/ffssa_synthesis_consultation.pdf ( Accessed on January 10, 2011). from Hungary, Poland and Bulgaria. World Bank, Washington D.C.

[13] Ibrahim, S.A and Hala, K (2007). Growth, yield and chemical constituents of corn (Zea mays L.) as affected by intervals. J. of Applied Sci. Res.,3(10): 1112-1120.

[14] Jayne, T., M. Rukuni, M. Hajek, G. Sithole. and G. Mudimu, (2007). "Structural adjustment and food security in Zimbabwe," in J. Wyckoff and M. Rukuni (Eds.). Toward an Integrated National Food Policy Strategy, Proceedings of tile Second National Consultative Workshop (Harare: University of Zimbabwe). pp. 8-50.

[15] Kabata-Pendias and Pendias, H., (2001). Trace Metals in Soils and Plants, CRC Press, Boca Raton, Fla, USA, 2nd edition.

[16] Lovei, M. and B.S. Levy (2000). Lead exposure and healh in Central Eastern Europe. Evidence

[17] Malomo. O., Ogunmoyela, O.A.B., Oluwajoba, S.O., Adekoyeni, O.O. (2012). Evaluation of chemical and heavy metal concentration in maize (Zea mays) from industrial areas of Ogun State. Journal of sustainable development 
and environmental protection.: 2(3):35-42

[18] Najat, K. M. (2008). Nuclear techniques applied to biological samples from Tanzania to monitor the nutritional status of children. A PhD thesis. Faculty of Engineering and Physical sciences, University of Survey

[19] Nelson, T. (1996). Closing the Nutrient Loop. World Watch (November/December)

[20] Nkansan, M. A. And Amoako, C.O (2010). Heavy metal content of some common spicies available in markets in the in the Kumasi metropolis of Ghana. American Journal of Scientific and Industrial Research 192):158-163.

[21] Olayemi, J.K. (1982): Improved Marketing as a Strategy for Generating Increased Food Production, A Nigeria Experience. West African Journal of Agricultural Economics, 1(1): $21-26$

[22] Ozkutlu F, Doguru, Y,Ozenc, N,Yazici, G, Tunan. Mand Akcay, F (2011). The importance of Turkish hazelnut trace and heavy metal contents for human nutrition. J. Soil and Environmental Management Vol2(10 pp.253)
[23] Punita Guria. (2006). Physico-chemical properties, nutritional quality and value addition to quality protein maize (Zea mays L.). A Thesis for Master of Home Science Submitted to the Department of Food Science and Nutrition, University of Agricultural Sciences, Dharwad.

[24] Solomons, N.W. and M. Ruz(1997). Nutrition research: 17, 177-183.

[25] WHO/FAO (1984). "The Role of food safety in health and development"- A Report of a Joint FAO/WHO Expert Committee on Food Safety.

[26] Williams, S.B (2007).Urban Aquaculture: Producer Perceptions and Practices in Lagos State, Nigeria. MiddleEast Journal of Scientific Research. 2(1):21-27.

[27] Zoubi, M. M. Al, Arslan, A. Abdelgawad, G. Pejon, N. Tabbaa, M. \& Jouzdan, O. (2008). The Effect of Sewage Sludge on Productivity of a Crop Rotation of Wheat, Maize and Vetch) and Heavy Metals Accumulation in Soil and Plant in Aleppo Governorate. American-Eurasian Journal of Agricultural \& Environmental Sciences. 3 (4), 618-625 